\title{
Orta Karadeniz Bölgesi Toprak Sıcaklığının Zaman Serisi Analizi Yöntemi İle Modellenmesi
}

\author{
Filiz KARA'**(D) \\ Bilal CEMEK² ID \\ 'Batı Akdeniz Tarımsal Araștırma Enstitüsü, Antalya \\ ${ }^{2}$ Ondokuz Mayıs Üniversitesi, Ziraat Fakültesi, Tarımsal Yapılar ve Sulama Anabilim Dalı, Samsun
}

\begin{abstract}
*Sorumlu yazar e-mail (Corresponding author e-mail): filiz.kara@tarimorman.gov.tr
Geliș tarihi (Received): 09.07.2019

Kabul tarihi (Accepted): 19.07.2019

DOI: $10.21657 /$ topraksu.655501
\end{abstract}

\section{Öz}

Bu çalıșma Orta Karadeniz Bölgesinin illerine ait farklı katmanlarda (5, 10, 20, 50, 100 cm) ölçülen aylık ortalama toprak sıcaklık değerlerinin Box Jenkins (BJ) tekniği ile tahmin edilmesi amaçlanmıștır. 1969-2013 yıllarına ait aylık ortalama toprak sıcaklık değerleri analiz edilerek mevsimsellikten arındırımıș daha sonra, olușan bu veri setlerine uygun modeller belirlenmiștir. 2013-2019 yılları arasındaki öngörüleri elde edilmiștir. Samsun, Amasya ve Ordu ilinin her bir katmanı için uygun model Mevsimsel Otoregrasyon olarak belirlenmiștir. Bu istasyonlara ait belirleme katsayısı $\left(R^{2}\right)$ değerleri 0.59-0.96 arasında, tahmin hatasının standart sapması (RMSE) değerleri 1.55-4.93 arasında ve ortalama mutlak hata (MAE) değerleri ise 1.24-4.28 değerleri arasında değișim göstermiștir. Tokat ve Çorum ilinin her bir katmanı için uygun model Mevsimsel Hareketli Ortalama olarak tespit edilmiștir. Bu istasyonlara ait belirleme katsayısı (R²) değerleri 0.83-0.95 arasında, tahmin hatasının standart sapması (RMSE) değerleri 1.79-4.68 arasında ve ortalama mutlak hata (MAE) değerleri ise 0.03-3.91 değerleri arasında değișim göstermiștir. Çalıșma sonucu zaman serisi modellerinin Orta Karadeniz Bölgesi illeri aylık ortalama toprak sıcaklık hesaplamalarında bașarılı sonuçlar verdiği görülmüștür.

Anahtar kelimeler : ARIMA modelleri, box jenkins tekniği, iklim, toprak sıcaklığı

\section{Modeling of Soil Temperature in Central Black Sea Region by Time Series Analysis Method}

\section{Abstract}

The aim of this study is to estimate the monthly average soil temperature measured in different layers $(5,10,20,50,100 \mathrm{~cm})$ of the Central Black Sea Region by Box Jenkins (BJ) technique. The monthly average soil temperature values of the years 1969-2013 were analyzed and seasonally adjusted and then the models suitable for these datasets were determined. The projections for 2013-2020 were obtained. The appropriate model for each layer of Samsun, Amasya and Ordu is determined as seasonal autoregression. The determination coefficient $\left(R^{2}\right)$ values of these stations are between 0.59-0.96, the standard deviation (RMSE) of the estimation error is between 1.55-4.93 and the mean absolute error (MAE) values are 1.24-4.28 values have changed. The appropriate model for each layer of Tokat and Çorum was determined as Seasonal Moving Average. The coefficient of determination $\left(R^{2}\right)$ of these stations is between 0.83-0.95 and the standard deviation (RMSE) of the estimation error is between 1.79-4.68 and the mean absolute error (MAE) is 0.03-3.91 values have changed. As a result of the study, it was seen that time series models yielded successful results in the monthly average soil temperature calculations in the Central Black Sea Region provinces.

Keywords: ARIMA models, box jenkins technique, climate, soil temperature 


\section{Gíriș}

Toprak sıcaklığı toprak içerisinde bitkisel üretimi etkileyen birçok fiziksel, kimyasal ve biyolojik faaliyeti etkilemektedir (Öztekin vd., 2008). Toprakta suyun bulunușu, hareketi, buharlașması ve hava kapasitesi, ayrıșması olayları, mikrobiyolojik faaliyet, kök solunumu ve vejetatif faaliyet gibi olayların tümü toprak sıcaklığının etkisi altındadır (Özkan, 1985; Karaman vd., 2007). Toprak profilinde sıcaklık günlük, aylık veya yıllık olarak değișim göstermektedir. Bu değișim bir gün veya bir yıl olmak üzere zamanın periyodik fonksiyonları șeklindedir. Toprak yüzeyinde sıcaklık değișimi fazla olup, așağı katmanlara doğru inildikçe azalmaktadır. Toprağın 35-100 cm derinliğinde ise sıcaklığın günlük değișimi pratik olarak sabit değerlere ulașmaktadır (Ekberli vd., 2005)

Toprak sıcaklığının kaynağı atmosferi geçerek yeryüzüne ulașan güneș ıșınlarıdır. Güneșten kaynaklanan enerji girișlerinin karșısında enerji kayıpları yer alır, bu kayıplar uzun zaman aralıklarında ve geniș bölgelerde enerji girișiyle yaklașık aynı büyüklüktedir. Bu durum, yer yüzeyinin sürekli güneșten gelen ıșınlara maruz kalmasına rağmen bir bütün olarak bakıldığında yüzeydeki sıcaklığının kuvvetlice değișmemesinden de anlașllabilir; böylece belirli yerler ve zaman aralıkları için ortalama toprak sıcaklıklarının belirtilmesi anlamlıdır (Schachtschabel, 1995).

Toprak sıcaklığının değișimi toprak rutubetinin değișimine ve toprakta su dengesinin olușumuna önemli etki yapmaktadır. Toprakta suyun tașınım potansiyeli, toprak sıcaklığı ve rutubetinin bir fonksiyonudur. Gözenekli bir yapıya sahip olan toprakta suyun buharlașarak tașınımı sıcaklık değișimi sonucunda olușmaktadır. Toprak profilindeki su buharı geceleri alt katmanlardan daha soğuk olan üst katmanlara doğru hareket etmektedir. Toprak nemi ve sıcaklık değișimleri arasındaki nicel bağımlıık, topraklar arasında farklılık göstermektedir (Gerayzade, 1989).

Bölgedeki tarımsal üretimde ürün kalitesini ve verimliliği arttırmak, ürün kayıplarını en aza indirmek, bölgenin doğal yapısını korumak, tarımsal üretimde uygun ürün çeșidini belirlemek, bölgede olası iklim değișikliğinde bölge șartlarına uygun ağaç cinslerini belirlemek ve toprağın mevcut özelliklerini korumak ve geliștirmek için toprak sıcaklıklarının bilinmesi gerekir. Bölgenin değișik topografik yapısı içerisinde her noktada sıcaklık ölçme imkânı olmadığından toprak sıcaklıklarının tahmin edilerek belirlenmesi önemlidir. Ayrıca, bölgede toprak sıcaklıklarının belirlenmesi ısı kazancı ve ısı kaybı hesaplarında net sonuçların ortaya çıkarılması açısından da büyük önem tașır (Bilgili vd., 2011).

1995 yılında IPCC'nin (ülkeler arası iklim değișikliği paneli) iklim modelleri ile yapılan projeksiyonlarına göre; 2030 yılına kadar Türkiye'nin büyük bir kısmının oldukça kuru ve sıcak bir iklimin etkisine gireceği, sıcaklıkların kıșın $2^{\circ} \mathrm{C}$, yazın ise $2^{\circ} \mathrm{C}$ ile $3^{\circ} \mathrm{C}$ artacağı öngörülmektedir (Kadıoğlu, 2009). Belirli bir problemi modellemek için uygun bir yöntem seçilmesi; modellenecek seri sayısı, gerekli doğruluk, modelleme girdileri, modelleri kullanma kolaylığı, sonuçları yorumlama kolaylığı gibi birçok faktöre bağlıdır (Mondal vd., 2006).

Zaman serileri kesikli, doğrusal ve stokastik süreç içeriyorsa Box Jenkins veya ARIMA modeli olarak adlandırılır. Bunlar doğrusal filtreleme modelleri olarak da bilinirler. Otoregresif (ARAutoRegressive) modelleri Yule (Yule, 1927) tarafından düșünülmüștür. Diğer bir model, hareketli ortalama (MA-Moving Average) ilk defa Slutsky (Slutsky, 1927) tarafından ortaya atılmıștır. AR ve MA modellerinin karıșım olan Otoregresif Hareketli Ortalama (ARMA - AutoRegressive Moving Average) modelleri ilk defa Wold (Wold, 1954) tarafından geliștirilmiștir. AR, MA, ARMA modelleri en genel doğrusal, durağan Box Jenkins modelleridir. Durağan olmayıp fark alma ișlemi sonucunda durağanlaștırılan serilere uygulanan modellere Birleștirilmiș Otoregresif Hareketli Ortalama (ARIMA-AutoRegressive Integrated Moving Average) modeli denilmektedir. Bu model Box Jenkins tekniği olarak da adlandırıır. Bu teknik derlenen kesikli zaman serilerinin ve dinamik sistemlerin modellenmesinde kullanılmaktadır. Box Jenkins modellerinde amaç; zaman serisine en iyi uyan, en az parametre içeren doğrusal modeli belirlemektir. Bu modelleme yardımıyla yolcu yoğunlukların dikkate alan dinamik çizelgeleme de yapılabilir (Yaman vd., 2001 ).

Zaman serileri analizinde kullanılan birçok yöntem vardır. Box-Jenkins yöntemi, doğrusal zaman serilerinin analizinde en bilinen ve en çok kullanılan metotlardan biridir. Doğrusal ve durağan süreçlerde ya da durağan olmayan fakat çeșitli 
istatistiksel yöntemlerle durağanlaștırılabilen serilerde Box-Jenkins yöntemi bașarıyla uygulanabilir. Ancak birçok zaman serisi doğrusal ilișkinin yanı sıra doğrusal olmayan ilișki de içermektedir.

\section{MATERYAL VE YÖNTEM}

Çalıșma alanı olarak Orta Karadeniz Bölgesi belirlenmiș olup, bölge illerinin 5 farklı toprak katmanındaki $(5,10,20,50,100 \mathrm{~cm})$ toprak sıcaklık değerleri Meteoroloji Genel Müdürlüğünden elde edilmiștir.

Çizelge 1. Meteroloji istasyonlarının kodları, konumları ve yükseklik değerleri

Table 1. Codes, locations and height values of meteorological stations

\begin{tabular}{lcccc}
\hline İ Adı & $\begin{array}{c}\text { İstasyon } \\
\text { Kodu }\end{array}$ & Enlem & Boylam & $\begin{array}{c}\text { Yükseklik } \\
(\mathrm{m})\end{array}$ \\
\hline Samsun & 17030 & $41^{\circ} 34^{\prime} \mathrm{K}$ & $36^{\circ} 25^{\prime} \mathrm{D}$ & 4 \\
Tokat & 17086 & $40^{\circ} 33^{\prime} \mathrm{K}$ & $36^{\circ} 55^{\prime} \mathrm{D}$ & 611 \\
Amasya & 17085 & $40^{\circ} 66^{\prime} \mathrm{K}$ & $35^{\circ} 83^{\prime} \mathrm{D}$ & 409 \\
Çorum & 17084 & $40^{\circ} 54^{\prime} \mathrm{K}$ & $34^{\circ} 93^{\prime} \mathrm{D}$ & 776 \\
Ordu & 17033 & $40^{\circ} 98^{\prime} \mathrm{K}$ & $37^{\circ} 88^{\prime} \mathrm{D}$ & 5 \\
\hline
\end{tabular}

Çalıșmada 1969-2013 yılları arasındaki veriler kullanılmıștır. Meteoroloji istasyonlarının kod, enlem, boylam ve yükseklik değerleri Çizelge 1.'de verilmiștir.

\section{Box Jenkins modeli}

Box Jenkins yöntemi tek değișkenli zaman serilerinin ileriye dönük tahmin ve kontrolünde kullanılan istatistiksel öngörü yöntemlerinden biridir. Zamana bağlı olayların rassal karakterde olaylar, bu olaylarla ilgili zaman serilerinin ise stokastik süreç olduğu varsayımına dayanarak geliștirilmiș olan bu yöntemin uygulandığı zaman serisinin eșit aralıklı gözlem değerlerinden olușan kesikli ve durağan bir seri olduğu varsayılmaktadır. Ancak gerçekte zaman serilerinin ortalama ve varyansında zamana bağlı olarak bir değișim olmaktadır. Durağan olmayan zaman serilerinde görülen bu değișim, genellikle trend, düzenli, düzensiz dalgalanmalar ve tesadüfi dalgalanmaların etkisiyle gerçekleșir. Durağan olmayan zaman serilerinin Box-Jenkins yöntemiyle öngörüsü için seri bazı dönüșüm yöntemleriyle durağan hale getirilmelidir.

Box-Jenkins Yöntemi ile öngörü dört așamada gerçekleșmektedir.

1. Model Belirleme: Zaman serisine uygun Box Jenkins modeli bu așamada belirlenir.
2. Parametre Tahmini: Model belirleme așamasında belirlenen modele ilișkin parametrelerin tahmin edildiği așamadır.

3. Uygunluğun Testi: Modelin veri setine uygunluğunun istatistiksel yöntemlerle test edildiği bu așamada model uygun bulunursa son așamaya geçilir, uygun bulunmazsa bașka bir modelin belirlenmesi için ilk așamaya dönülür.

4. Tahmin: Seçilen en uygun model tahmin için kullanılır.

Box-Jenkins Yöntemi ile tahmin edilen zaman serisi modelleri; Otoregresif (AR) Modeli, Hareketli Ortalama (MA) Modeli, Otoregresif-Hareketli Ortalama (ARMA) Modeli ve Otoregresif Bütünleșik Hareketli Ortalama (ARIMA) Modelidir.

ARIMA modelleri, durağan olmayan ancak fark alma ișlemiyle durağan hale dönüștürülmüș serilere uygulanan modellerdir. Durağan olmayan ancak fark alma ișlemiyle durağan hale dönüștürülmüș serilere uygulanan modellere "durağan olmayan doğrusal stokastik modeller" denir. Bu modeller d dereceden farkı alınmıș serilere uygulanan, değișkenin t-dönemindeki değerinin belirli sayıdaki geri dönem değerleri ile aynı dönemdeki hata teriminin doğrusal bir fonksiyonu olarak ifade edildiği AR ve değișkenin t-dönemindeki değerinin aynı dönemdeki hata terimi ve belirli sayıda geri dönem hata terimlerinin doğrusal fonksiyonu olarak ifade edildiği MA modellerinin birer birleșimidir. Modellerin genel gösterimi ARIMA ( $p$, d, q) seklindedir. Burada p ve q sırasıyla Otoregresif (AR) Modelin ve Hareketli Ortalama (MA) Modelinin derecesi, $d$ ise fark alma derecesidir.

Genel ARIMA(p,d,q) modeli așağıdaki gibi formüle edilir.

$\mathrm{Zt}=\Phi 1 \mathrm{Zt}-1+\Phi 2 \mathrm{Zt}-2+\ldots+\Phi \mathrm{pZp}-1+\delta+\alpha \mathrm{t}-\Theta 1 \alpha \mathrm{t}-1-$ $\Theta 2 \alpha t-2-\ldots-\oplus q \alpha t-q$

Burada Zt, Zt-1,.., Zp-1 d dereceden farkı alınmıș gözlem değerlerini, $\Phi 1, \Phi 2, \ldots, \Phi p d$ dereceden farkı alınmıș gözlem değerleri için katsayıları, $\delta$ sabit değeri, $\alpha \mathrm{t}, \alpha \mathrm{t}-1, \ldots, \alpha \mathrm{t}-\mathrm{q}$ hata terimlerini ve $\Theta 1, \Theta 2, \ldots, \Theta q$ hata terimleri ile ilgili katsayıları göstermektedir (Kaynar ve Taștan, 2009).

Box Jenkins modeline yönelik modelleme tekniği

Olasılığa dayalı modellemede temel olarak dört ardıșık fakat tekrarlı așama vardır. Aynı șekilde 
mevsimsel ARIMA modelleme yaklașımında bu dört așama șunları kapsamaktadır: (i) $(p, d, q) X$ $(P, D, Q) S$ șeklinde mevsimsel ARIMA yapısının belirlenmesi, (ii) model parametrelerinin tahmin edilmesi, (iii) model kalıntılarının tanısal kontrolü ve (iv) bilinen verilere dayalı olarak tahmin edilen değerlerin üretimi (Box vd., 1970; Brockwell vd., 2002). Ne var ki birden üçe kadar olan așamalar temel olarak model kalibrasyon ișlevleridir ve son așama da oturmuș modelin yeterliliğinin kontrol edilmesine yöneliktir. İlk olarak gözlemlenen zaman serileri, gözlemlenen verilerin uygun șekilde farklılaștırıması yönteminin uygulanmasiyla sabit hale getirilmelidir. Bu sabit zaman serilerinden, sıklıkla ilgisiz verilerin dâhil edilmemesi șekilde bahsedilir. Belirleme așamasında dönemsel, otokolerasyon ișlevi (ACF) ve kısmi otokolerasyon ișlevleri (PACF) gibi grafiksel yöntemler, mevsimselliği ve ön belirleme sırasını tespit etmek için yararlıdır. Mevsimsel ARIMA modelleme yaklașımının belirleme așaması, gözlemlenen verilerin geçici olarak ilgisiz zaman serilerindeki model șeklini belirlemek amacıyla bu ișlevleri kullanır. Mevsimsel ARIMA model yapısının belirlenmesinden sonra model parametreleri, maksimum olasılık yöntemi ile tahmin edilir (Box vd., 1970).

Daha sonra geliștirilen tüm modeller, hata parametreleri açısından karșılaștırııır. Sonrasında uygun model seçilir ve çalıșma alanı içerisindeki her bir katman için toprak sıcaklığı değerleri tahmin ișlemi gerçekleștirilir. Çalıșmada MINITABv16 istatistik yazılım paketi kullanılarak Box Jenkins ARIMA modelinin analizi yapılmıștır.

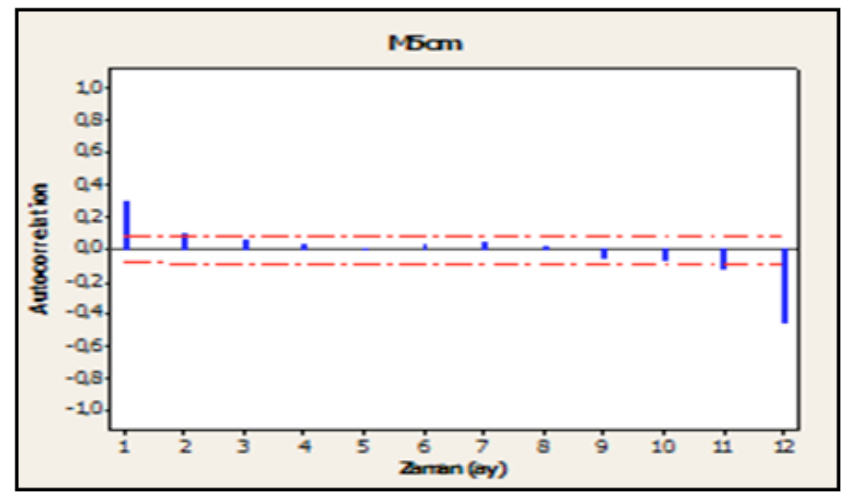

(a)

\section{Box Jenkins tekniğinin uygulanması}

Box Jenkins tekniğinde uygun modelin belirlenmesinde ilk așama olan geçici modelin saptanması için ACF grafiği ile PACF grafiği her ilin farklı katmanları için ayrı çizilmiștir.

Samsun ili için 5 cm'deki toprak sıcaklık değerlerinin ACF grafiğine bakıldığında serinin durağanlaștığı görüldüğünden seriye daha fazla fark ișlemi uygulanmamıștır (Șekil1a). ACF grafiğindeki ilișki miktarları gecikme sayısı arttıkça yavaș azalmakta olup, PACF grafiğinde bu azalma hızlı bir șekilde olduğu için model olarak Otoregresyon Modeli olduğu saptanmaktadır. Ayrıca PACF grafiğinde birinci gecikmede kesin bir çıkıș gözlenmektedir, bu durum da tipik bir Otoregresif süreç göstergesidir (Șekillb). Dolayısıyla Șekill'e göre seriye uygun model ARIMA $(1,1,0) \quad(1,1,0) 12$ olmaktadır. Samsun ilinin diğer toprak sıcaklığı katmanları $(10,20$, 50 ve $100 \mathrm{~cm}$ ) için BJ tekniği uygulanmıș ve bu katmanlar içinde Otoregresyon Modeli ARIMA $(1,1,0) \quad(1,1,0) 12$ en iyi model olduğu tespit edilmiștir.

Tokat, Çorum, Amasya ve Ordu illerine ait ACF ve PACF grafikleri incelendiğinde sırasıyla zaman serisi için en iyi modeller Mevsimsel Hareketli Ortalama modeli $\operatorname{ARIMA}(0,1,1)$ $(0,1,1) 12$, Mevsimsel Hareketli Ortalama modeli ARIMA $(0,1,1)(0,2,1) 12$, Mevsimsel Otoregasyon modeli ARIMA $(1,1,0) \quad(1,2,0) 12$ ve Mevsimsel Otoregasyon modeli $\operatorname{ARIMA}(1,1,0) \quad(1,1,0) 12$ olduğu tespit edilmiștir (Șekil2-3-4-5). Ayrıca illere ait diğer toprak katmanları için yapılan BJ analizinde de aynı modeller en iyi sonucu vermiștir.

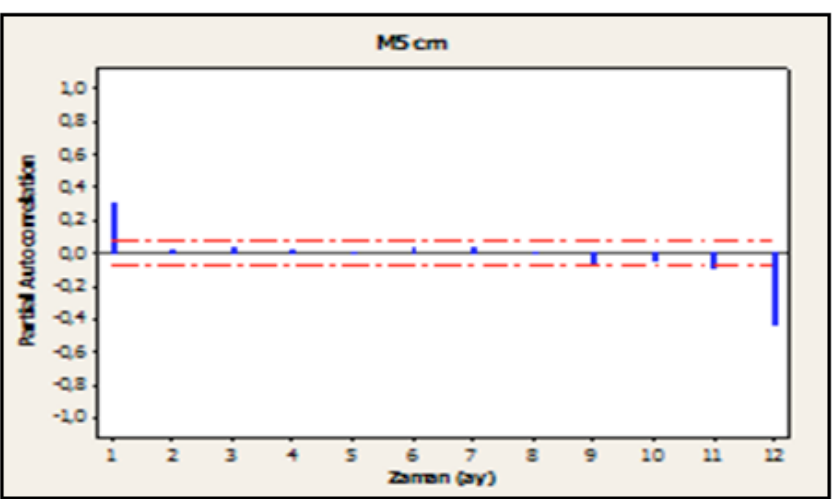

(b)

Șekil 1. Samsun ili 5 cm'deki toprak sıcaklık değerlerinin ACF (a) ve PACF (b) grafiği

Figure 1. ACF (a) and PACF (D) graph of soil temperature values at $5 \mathrm{~cm}$ in Samsun province 


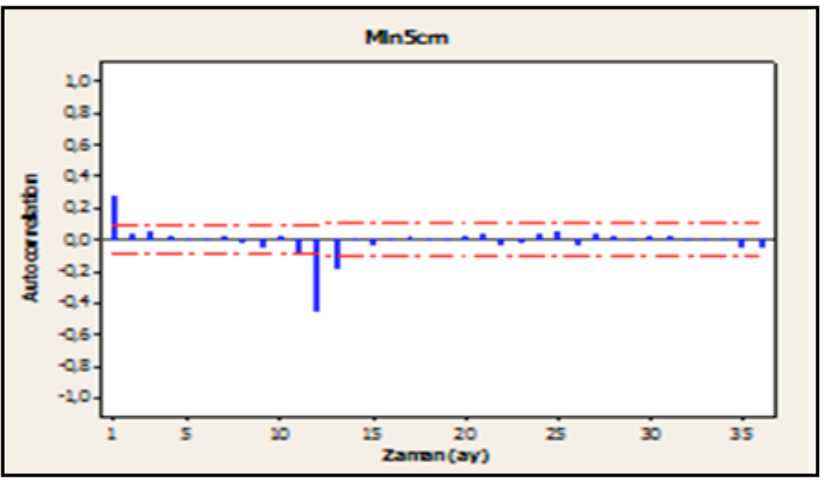

(a)

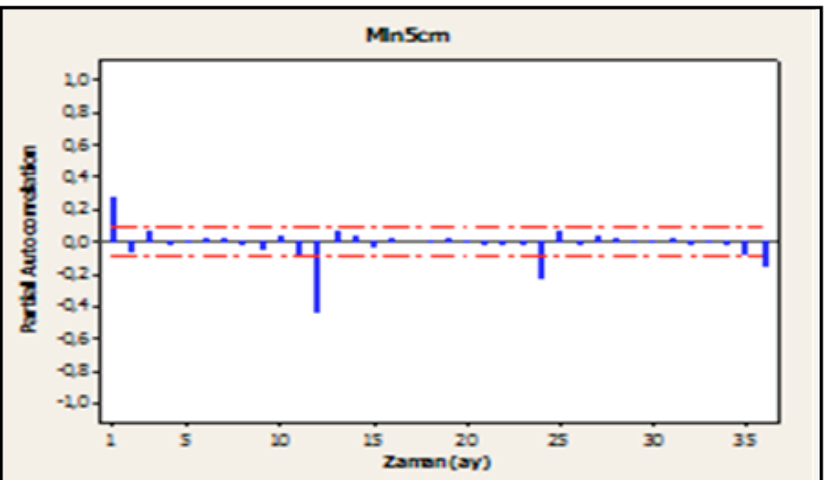

(b)

Sekil 2. Tokat ili $5 \mathrm{~cm}$ 'deki toprak sıcaklık değerlerinin ACF (a) ve PACF (b) grafiği

Figure 2. ACF (a) and PACF (b) graph of soil temperature values of $5 \mathrm{~cm}$ in Tokat province

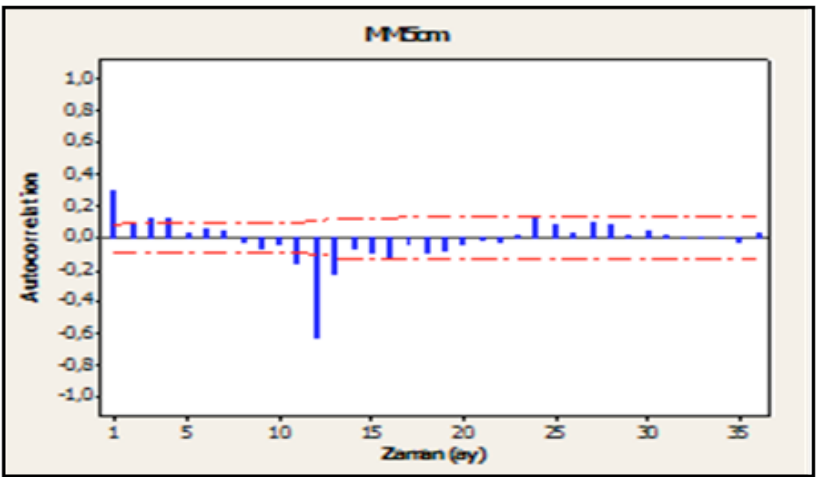

(a)

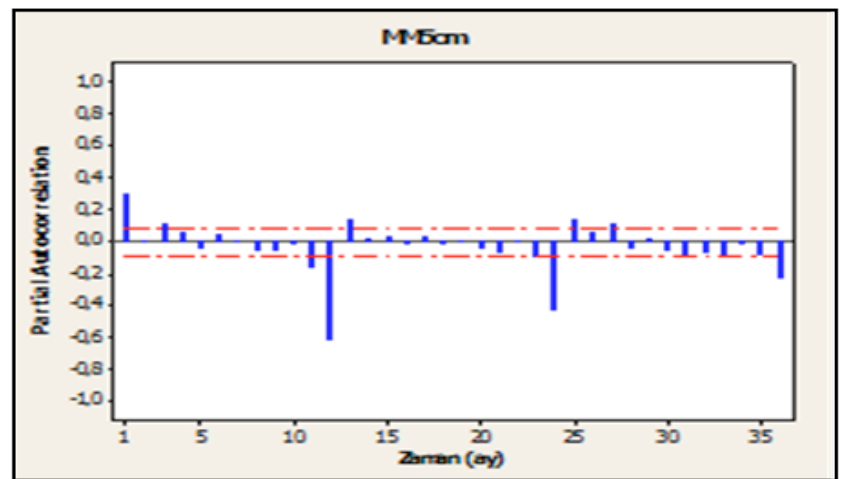

(b)

Șekil 3. Corum ili 5 cm'deki toprak sıcaklık değerlerinin ACF (a) ve PACF (b) grafiği

Figure 3. ACF (a) and PACF (b) graph of soil temperature values of $5 \mathrm{~cm}$ in Corum province
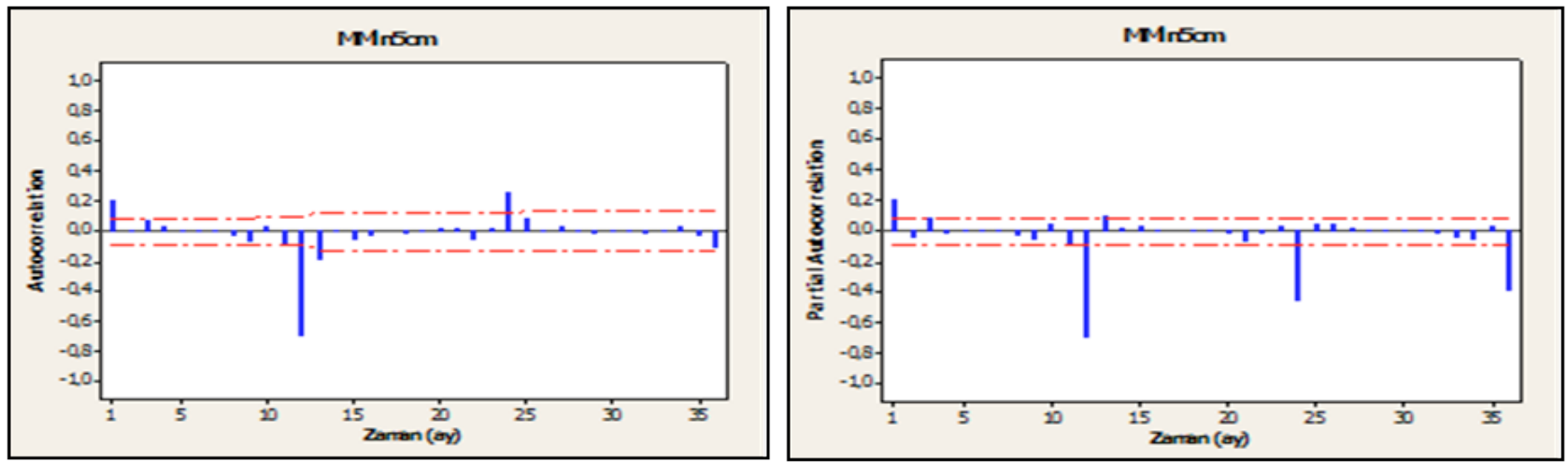

Șekil 4. Amasya ili $5 \mathrm{~cm}$ 'deki toprak sıcaklık değerlerinin ACF (a) ve PACF (b) grafiği

Figure 4. $A C F(a)$ and PACF (b) of soil temperature values of $5 \mathrm{~cm}$ in Amasya province

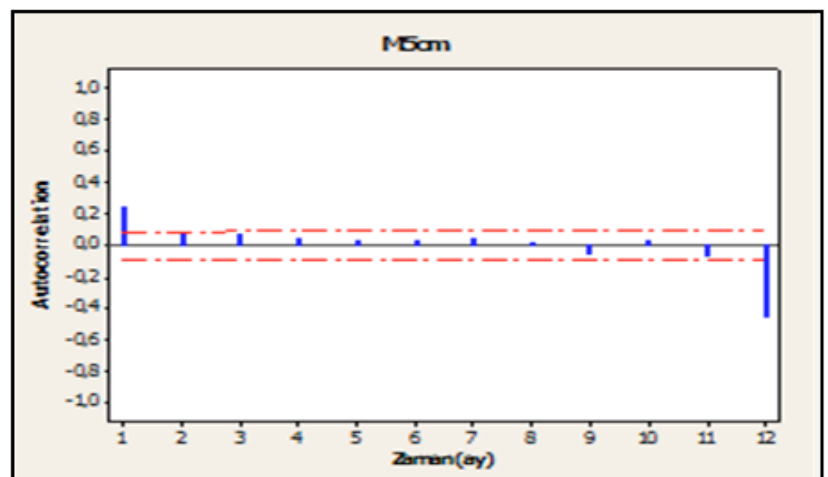

(a)

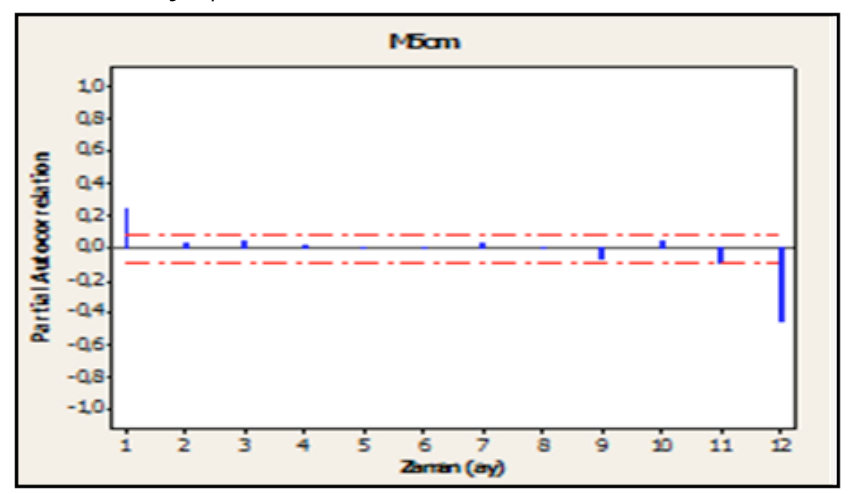

(b)

Șekil 5. Ordu ili $5 \mathrm{~cm}$ 'deki toprak sıcaklık değerlerinin ACF (a) ve PACF (b) grafiği

Figure 5. ACF (a) and PACF (b) of soil temperature values of $5 \mathrm{~cm}$ in Ordu province 


\section{Model parametrelerinin tahmini}

Her modelin parametresi, MINITABv 16 istatistik yazılımının ARIMA modülü ile tahmin edilmiștir ve sonuçlar Çizelge 2'de sunulmuștur. Katsayılar anlamlı bir șekilde sıfırdan

\section{Model parametrelerinin tahmini}

Her modelin parametresi, MINITABv16 istatistik yazılımının ARIMA modülü ile tahmin edilmiștir ve sonuçlar Çizelge 2 'de sunulmuștur. Katsayılar anlamlı bir șekilde sıfırdan büyüktür (It-değeril>2.0) ve sabitlik koșullarını karșılamaktadır. Tüm katsayılar için mutlak değerler de 1.0'dan anlamlı șekilde farklıdır.

Çizelge 2. Illerin mevsimsel ARIMA modelinin tahmini parametreleri değerleri

Table 2. Estimated parameters of seasonal ARIMA model of provinces

\begin{tabular}{|c|c|c|c|}
\hline \multicolumn{4}{|c|}{ Samsun ARIMA $(1,1,0)(1,1,0) 12$} \\
\hline Model & Parametre & Standart Hata & t-değeri \\
\hline Parametreleri & Değeri & Katsayısı & \\
\hline AR & -0.344 & 0.037 & -9.2 \\
\hline SAR & -0.465 & 0.035 & -13.1 \\
\hline Sabit & -0.001 & 0.079 & -0.02 \\
\hline \multicolumn{4}{|c|}{ Tokat ARIMA $(0,1,1)(0,1,1) 12$} \\
\hline AR & 0.872 & 0.022 & 38.56 \\
\hline SAR & 0.954 & 0.038 & 24.79 \\
\hline Sabit & 0 & 0 & 0.13 \\
\hline \multicolumn{4}{|c|}{ Çorum ARIMA $(0,1,1)(0,2,1) 12$} \\
\hline AR & 0.73 & 0.031 & 23.32 \\
\hline SAR & 0.953 & 0.036 & 26.09 \\
\hline Sabit & -0.001 & 0.008 & -0.15 \\
\hline \multicolumn{4}{|c|}{ Amasya ARIMA $(1,1,0)(1,2,0) 12$} \\
\hline$A R$ & -0.397 & 0.041 & -9.56 \\
\hline SAR & -0.847 & 0.024 & -34.39 \\
\hline Sabit & -0.002 & 0.082 & -0.03 \\
\hline \multicolumn{4}{|c|}{ Ordu ARIMA $(1,1,0)(1,1,0) 12$} \\
\hline AR & -0.406 & 0.04 & -10.05 \\
\hline SAR & -0.66 & 0.034 & -19.48 \\
\hline Sabit & 0.006 & 0.124 & 0.05 \\
\hline
\end{tabular}

\section{BULGULAR VE TARTIȘMA}

\section{Box Jenkins tekniği bulguları}

Olușturulan modeller içerisinde $\mathrm{R}^{2}$, RMSE ve MAE kriterleri kullanılarak yapılan karșılaștırma sonucunda veri setine en uygun olan model; Samsun ilinin her bir katmanı için Mevsimsel Otoregrasyon modeli (ARIMA $\left.(1,1,0)(1,1,0)_{12}\right)$, Tokat ilinin her katmanı için Mevsimsel Hareketli
Ortalama $\quad\left(\operatorname{ARIMA}(0,1,1) \quad(0,1,1)_{12}\right), \quad$ Corum ilinin her katmanı için Mevsimsel Hareketli Ortalama (ARIMA $\left.(0,1,1) \quad(0,2,1)_{12}\right)$, Amasya ilinin her katmanı için Mevsimsel Otoregrasyon (ARIMA $\left.(1,1,0)(1,2,0)_{12}\right)$, Ordu ilinin her katmanı için Mevsimsel Otoregrasyon (ARIMA $(1,1,0)$ $\left.(1,1,0)_{12}\right)$, modeli belirlenmiș ve zaman serisinin tahmini için kullanılmıștır. Çizelge 3'de seçilen en iyi modeller ve karșılaștırılması yapılan gerçek ve tahmini değerlerin RMSE, MAE ve $\mathrm{R}^{2}$ değerleri yer almaktadır.

Çizelge 3. Seçilen en iyi modellerin test ve validasyon değerleri için RMSE, MAE ve $R^{2}$ değerleri

Table 3. ERMSE, MAE and $R^{2}$ values for test and validation values of selected best models

\begin{tabular}{ccc}
\hline \multicolumn{3}{c}{ Samsun } \\
\hline RMSE & MAE & $R^{2}$ \\
\hline
\end{tabular}

Derinlik
$(\mathrm{cm})$

\begin{tabular}{|c|c|c|c|c|c|c|}
\hline \multicolumn{7}{|l|}{1} \\
\hline & 2.11 & 2.68 & 1.76 & 2.14 & 0.96 & 0.94 \\
\hline 10 & 4.89 & 2.33 & 4.12 & 1.90 & 0.87 & 0.95 \\
\hline 20 & 3.97 & 1.53 & 3.33 & 1.24 & 0.90 & 0.96 \\
\hline 50 & 3.98 & 1.75 & 3.40 & 1.42 & 0.89 & 0.96 \\
\hline 100 & 1.50 & 4.92 & 1.21 & 4.28 & 0.95 & 0.77 \\
\hline \multicolumn{7}{|c|}{ Tokat } \\
\hline 5 & 1.75 & 2.33 & 1.39 & 1.81 & 0.97 & 0.95 \\
\hline 10 & 1.68 & 3.95 & 1.35 & 3.12 & 0.97 & 0.93 \\
\hline 20 & 2.36 & 3.78 & 1.95 & 2.99 & 0.95 & 0.93 \\
\hline 50 & 1.42 & 2.67 & 1.13 & 2.11 & 0.97 & 0.95 \\
\hline 100 & 0.95 & 4.68 & 0.75 & 3.91 & 0.97 & 0.83 \\
\hline \multicolumn{7}{|c|}{ Corum } \\
\hline 5 & 4.06 & 3.00 & 3.25 & 2.16 & 0.90 & 0.90 \\
\hline 10 & 5.88 & 2.46 & 4.56 & 1.89 & 0.80 & 0.92 \\
\hline 20 & 3.53 & 3.13 & 1.83 & 0.03 & 0.87 & 0.89 \\
\hline 50 & 2.77 & 2.16 & 2.20 & 1.54 & 0.91 & 0.91 \\
\hline 100 & 3.79 & 1.79 & 2.89 & 1.39 & 0.81 & 0.90 \\
\hline \multicolumn{7}{|c|}{ Amasya } \\
\hline 5 & 3.67 & 3.50 & 2.70 & 2.73 & 0.88 & 0.90 \\
\hline 10 & 5.82 & 4.93 & 4.01 & 3.84 & 0.71 & 0.83 \\
\hline 20 & 3.70 & 4.40 & 2.81 & 3.19 & 0.85 & 0.84 \\
\hline 50 & 3.31 & 3.87 & 2.49 & 2.88 & 0.82 & 0.82 \\
\hline 100 & 4.33 & 4.31 & 3.16 & 3.19 & 0.76 & 0.77 \\
\hline \multicolumn{7}{|c|}{ Ordu } \\
\hline 5 & 1.64 & 3.49 & 1.26 & 2.84 & 0.96 & 0.92 \\
\hline 10 & 1.70 & 4.13 & 1.34 & 3.39 & 0.96 & 0.90 \\
\hline 20 & 1.75 & 4.82 & 1.44 & 3.78 & 0.96 & 0.78 \\
\hline 50 & 1.40 & 4.14 & 1.16 & 3.46 & 0.96 & 0.85 \\
\hline 100 & 2.40 & 4.05 & 2.05 & 2.81 & 0.91 & 0.59 \\
\hline
\end{tabular}




\section{SONUC̣LAR}

Bu çalıșma, Orta Karadeniz Bölgesine ait 5, 10, 20, 50 ve $100 \mathrm{~cm}$ 'deki aylık ortalama toprak sıcaklıklarını tahmin etmek için ARIMA yöntemi kullanılmıștır.ARIMA modeli ile tahmin edilen toprak sıcaklığı değerleri, 2014 ve 2015 yıllarına ait ölçülen aylık ortalama toprak sıcaklığı değerleri ile karșılaștırıldığında; Samsun ilinin 5 cm derinliğindeki toprak sıcaklığı tahmininde ARIMA ile geliștirilen modelde $R^{2}$ değeri 0.97 , Tokat ili için $R^{2}$ değeri 0.93, Corum ili için $R^{2}$ değeri 0.94 ve Amasya ili için $R^{2}$ değeri 0.92 ve Ordu ili için $R^{2}$ değeri 0.95 olup Șekil 5'de sapma grafikleri verilmiștir.

Bölgenin tarımsal üretimini geliștirmek ve meteorolojik verilerini ortaya çıkarmak için toprak sıcaklıklarının belirlenmesi oldukça önemli bir çalıșmadır. Farklı noktalarda inșa edilecek yapıların ısı kazancı ve ısı kaybı hesaplamalarında, toprak temaslı yapı elemanlarının izolasyon kalınlıklarının tespitinde de toprak sıcaklıklarının belirlenmesi gereklidir. Ayrıca bölgede toprak kaynaklı ısı pompası tasarımında, proje hesaplamalarında da toprak sıcaklığı değerlerinin önemi büyüktür. Bölgenin değișik topografik yapısı içerisinde her noktada sıcaklık ölçme imkanı da bulunmamaktadır. Geliștirilen bu model ile ölçüm yapılmayan bir hedef noktanın farklı derinliklerdeki ortalama toprak sıcaklığı, sadece topografik bilgiler kullanarak hızı ve az hata ile tahmin edilebilir. Bu yöntem, Türkiye'nin diğer bölgelerindeki meteoroloji istasyonları için de tahmin modeli olușturularak uygulanabilir.

\section{KAYNAKLAR}

Bilgili M (2011). The use of artificial neural networks for forecasting the monthly mean soil temperatures in Adana, Turkey, Turk J Agric For 35 (2011) 83-93, Tübitak.

Box GEP, Jenkins GM (1970). Time Series analysis, forecasting, and control. Oakland, CA: Holden-Day.
Brockwell P J, Davis R A (2002). An introduction to time series and forecasting, Springer, DOI: 10.1007/978-1-47572526-1.

Ekberli i, Gülser Ç, Özdemir N (2005). Toprakların termofiziksel özelliklerive ısısal yayınım katsayısının değerlendirilmesi, OMÜ Zir. Fak. Dergisi, 20 (2):85-91.

Gerayzade AP (1989). Toprak Bitki Atmosfer Sisteminde Enerji Döngüsü, Baku, Elm, s.158.

Karaman MȘ, Brohi AR, Müftüoğlu NM, Zengin M (2007). Sürdürülebilir toprak verimliliği, Koyulhisar Ziraat Odası Kültür Yayınları No: 1.

Kaynar O, Taștan S (2009). Zaman serisi analizinde mlp yapay sinir ağları ve arima modelinin karșılaștırılması, Erciyes Üniversitesi İktisadi ve İdari Bilimler Fakültesi Dergisi, Sayı:33, Temmuz-Aralık, ss. 161-172.

Mondal MS, Wasimi SA (2006). Generating and forecasting monthly flows of the Ganges River With PAR Model, Journal of Hydrology, 323(1-4), 41-56.

Özkan Ai (1985). Toprak fiziği, Ankara Üniversitesi, Ziraat Fakültesi Yayınları:946, Ders Kitabı: 270.

Öztekin T, Öztekin S, Oğuz i (2008). Koșullarında saatlik torak sıcaklıklarının periyodik sinüs dalga eșitliği ile tahmini, Tarım Bilimleri Araștırma Dergisi, 1 (1), 55-60.

Schachtschabel P, Blume H P, Brümmer G, Hartge K H, Schwertmann U (1995). Toprak bilimi, Çukurova Üniversitesi Ziraat Fakültesi Genel Yayın No:73, Ders Kitapları Yayın No: 16 .

Slutsky E (1927). The Summation of random causes as the source of cyclic processes, problems of economic conditions, 3, 1; English trans ,In Econometrica, 5, 105.

Wold HO (1954). A study in the analysis of stationary time series, Almquist and Wicksell, Uppsala.

Yaman K, Sarucan A, Atak M, Aktürk N (2001). Görüntü ișleme yöntemiyle hızı raylı ulașım sisteminde yolcu yoğunluğunun Box-Jenkins yaklașımı ile modellenmesi, Yöneylem Araștırması ve Endüstri Mühendisliği 22. Ulusal Kongresi, Gazi Üniversitesi, Ankara, 78, 4-6 Temmuz.

Yule GU (1927). On a method of investigating periodicities in disturbed series with special reference to Wölfer's Sunspot Numbers, Phil. Trans., A226, 267. 